\title{
Co-creation experience and place attachment: festival evaluation
}

\begin{abstract}
Adopting customer-to-customer value co-creation logic, this study explored the underlying dimensions of the co-creation experience and its effects on the behavioral intention to attend festivals. The analysis focused on the role of place attachment and festival satisfaction as mediators in the relationship between festival visitors' satisfaction with the co-creation experience and their behavioral intention to attend the festival. Drawing on 444 survey responses, our findings support the mediation roles of place dependence and festival satisfaction. The findings did not vary between tourists and residents. This suggests that facilitating shared consumption of festivals motivates festival attendees to re-patronize specific festivals. Based on these findings, both theoretical and practical implications of this analysis are discussed.
\end{abstract}

KEYWORDS: cultural festival, co-creation, place attachment, satisfaction, customer-tocustomer logic

Dr. Carol X Zhang Senior Lecturer in Marketing, University of Portsmouth carol.zhang@port.ac.uk

Dr. Lawrence Fong. Assistant Professor, University of Macau lawrencefong@um.edu.mo

Prof. Shina Li*, Professor, Sun Yet-Sen University, lishina@mail.sysu.edu.cn 


\section{INTRODUCTION}

Globalization, competition and cultural convergence have made the search for uniqueness a central issue for destinations (Anholt, 2002). Recognizing the changing role of consumers from passive receivers to active creators, marketing and tourism research has focused on the role cocreation has played in building a unique customer experience (e.g., Harkison, 2018; Prahalad \& Ramaswamy, 2004). Vargo and Lusch (2008) proposed the concept of co-creation based on service-dominant logic (S-D logic), which highlights the joint role of service providers and consumers in value co-creation. In the general tourism setting, researchers have asserted that the more tourists engage in the co-creation process, the more likely they are to have a positive experience (Mathis et al., 2016). With this potential benefit, the majority of co-creation tourism studies have focused on how and why customers co-create with service providers (e.g., Busser \& Shulga, 2018; Cabiddu, Lui \& Piccoli, 2013; Mathis et al., 2016). Others have focused on customer behavior within the value co-creation process (e.g., Yi \& Gong, 2013).

Including consumers in the production experience creates unique value for them. However, the dominant S-D logic approach to co-creation does not apply to all tourism experiences, especially festival tourism. Because experiential festival value outcomes cannot be predesigned or pre-delivered, exploring value co-creation between providers and consumers cannot yield a complete picture of the value derived from festival tourism (Rihova et al., 2015). Tourism is fundamentally about people traveling away from home to interact with different people and places (Sharpley, 2014). Thus, customer-dominant logic (C-D logic), highlighting the importance of customers' shared consumption in value creation, is arguably more suited to understanding the co-creation process within tourism settings, especially festival tourism, and recognizing the role of customers as co-creators of the festival experience (Getz, 2010; Rihova et al., 2015).

The growth of festivals and events worldwide has often been regarded as an important element in maintaining and reproducing the unique features of destinations. Festivals often emphasize the exceptional cultural and physical aspects of host destinations to attract visitors and encourage them to revisit (Getz, 2010). When they are seen as both events and tourism activities, festivals can be used to distinguish a destination from its competitors (Imbeah, Hodibert \& Amankwa, 2016). Recent studies, however, have found that by providing over commoditized homogenous experiences, festivals have become less distinctive and are failing to contribute to 
their destination's uniqueness (Davis, 2017). In response to this, researchers have recognized that psychological bonding with the host destination, also called place attachment, is a crucial dimension of a festival's uniqueness and visitors' behavioral intentions (e.g., Davis, 2017; Lee, 2001; Lee, Kyle \& Scott, 2012; Yolal et al., 2016). Suntikul and Jachna (2016) argued that because tourism fundamentally aims to enhance the experiential value for tourists, this value should be co-created with the destinations' unique physical features. For them, both co-creation experience and place attachment address "essential aspects of tourists' emotional engagement with tourism experience" (p.278). As the first attempt to link co-creation and place attachment, Suntikul and Jachna's study bears an obvious resemblance to the conceptualization of cocreation using C-D logic; however, the study does not investigate any forms of evaluation of such an experience, nor does it explicitly test the relationship between value co-creation and place attachment.

To fill this research gap, this research aims to empirically understand the embedded customer-to-customer value co-creation in festival attendees' experience, and its effects on festival behavioral intention at given destinations. In particular, it proposes a conceptual model (Figure 1) to examine the relationship between satisfaction with the co-creation experience, place attachment and festival evaluation. This model is examined in the context of the Macao International Parade in Macao. Specifically, this study makes three main contributions. First, the majority of the existing studies have adopted the S-D logic, which may not be suitable in festival settings. This study enriches value theory by providing a further insight into value co-creation using C-D logic, which seems more appropriate in the festival context. Second, the study enriches the research on co-creation through evaluating the serial mediating roles of festival satisfaction and place attachment. Co-creation and place attachment have an extensive history of being applied to a variety of marketing issues, even though their relationship with each other has remained unexplained. By incorporating the emotional relationship that individuals form with specific destinations (place attachment), this study provides theoretical and empirical evidence to advance knowledge on the mechanism that leads co-created shared festival experience at a given destination to the festival's evaluation. Third, given that the co-creation experience for both residents and tourists has not yet been fully and jointly investigated, the study attempts to test whether local attendees significantly differ from tourists in regard to the relationship between cocreation experience and festival evaluation. 


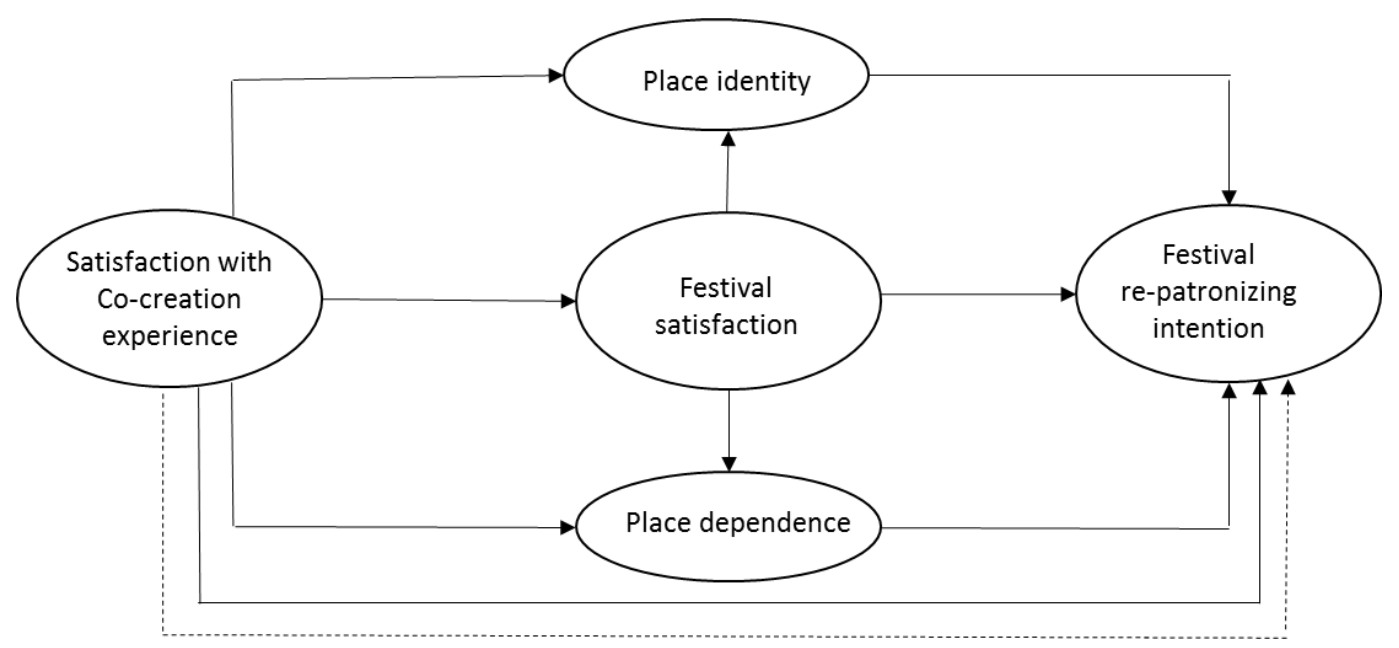

Figure 1: A hypothesized conceptual model

\section{LITERATURE REVIEW}

In this review, a conceptual overview of experience value in festival tourism, co-creation, satisfaction with co-creation experience, place attachment (place identity and place dependence) and festival evaluation was provided, following by detailed discussions on the hypothesized relationships based on theory and existing empirical research.

\subsection{Creating experience value in festival tourism}

Tourism is known as the industry that sells experiences. For many, tourism experience consists of both peak experiences, something extraordinary, and banal experiences, something mundane, which enable the peak experience (e.g., Quan \& Wang, 2004). All of the narratives contribute to reinforcing a coherent narrative that tourism experience is designed to offer hedonistic feelings to consumers (Prebensen, Vittersø \& Dahl, 2013; Prebensen, Chen \& Uysal, 2014; Ryan, 2010). Similarly, Pine and Gilmore (1999) argue that the central characteristic of the present economy is experience. Successful experiences are described as anything that customers find unique and memorable. Here, the creation of experience is considered as an evolved form of creating value (Pine \& Gilmore, 1999). The boom in the tourism industry reflects this experience economy. As Richards (1999) reflected, individuals have been focused on consumption away from physical 
goods toward service and experience. He further concluded that quality of life is increasingly judged in terms of access to those valuable experiences.

Many studies have recognized the intimacy between value and tourism experience. When understanding the tourism product and service, studies have addressed the customer value, the desired outcome for the customer, as a subjective experience (Grönroos, 2011). Experience and value are personal and interactive (Holbrook, 1999; Pine \& Gilmore, 1999). Ongoing research in academia and the popular press indicates that tourists are gaining more power over what goes into the nature of tourism products as experience (Binkhorst \& Dekker, 2009). The rise of customer role will inevitably influence the interactions between tourists and tourism providers from which value is derived (Campos et al., 2018; Prahalad \& Ramaswamy, 2004).

Tourism experiences are fundamentally related to co-creation value. Tourists travel away from their home environment and interact with various tourism stakeholders to create a unique and personal experience (Binkhorst \& Dekker, 2009). Hence, creating value in the tourism experience "is greatly focused on the role of the tourist as a consumer and the destination setting and the service company as the producer or provider in the co-creation process" (Prebensen, Chen \& Uysal, 2014: 2). Tourism providers have begun to encourage the collaboration of consumers in the co-creation of their own experiences to ensure personal and interactive experiences that are more related to customers' subject needs (Campos et al., 2018).

While co-creation of experience is essential for all types of tourism experience, creating a tourism experience is context specific. Festival tourism has been regarded as an important element in promoting the unique features of a destination due to its emphasis on the exceptional cultural and physical uniqueness of destinations that can create a valuable tourism experience (Getz, 2010). For example, del Barrio, Devesa and Herrero (2012) conceptualize festivals as a type of experiential goods that not only express artistic innovations in the field, but also draw on previous cultural backgrounds and current cultural settings, perceived as accumulated cultural capital. For festival organizers, festivals not only provide a unique destination experience for tourists, but also promote community values, identity and continuity for their local attendees (Getz \& Page, 2016). To provide a valuable festival experience, festival organizers must efficiently manage all of the activities involved in the creation and development of a festival for both tourists and local attendees (Jensen, 2014; Rihova et al., 2015, 2018). Among those 
activities, dramatized and interactive performances have been documented to have great effects on attendees' experience evaluation (Cole \& Chancellor, 2009).

\subsection{The concept of co-creation in festival tourism}

Customers are always co-creators of value (Vargo \& Lusch, 2004). Co-creating value in tourism is about the process through which customers interact with the company and generate their own experience (Binkhorst \& Dekker, 2009). Thus, to study value co-creation in the tourism context it is necessary to analyze the dynamic interactions between tourists and different tourism stakeholders (e.g., Busser \& Shulga, 2018; Suntikul \& Jachna, 2016). With different degrees of interaction between tourists and others, there are three major categories in value theory that explain value co-creation in service marketing including tourism: "goods-dominant" (G-D) logic, service-dominant (S-D) logic and customer-dominant (C-D) logic. In outcome-oriented G-D logic, value is viewed as an attribute embedded in a service that can be "exchanged" to realize benefits for the customer (Vargo \& Lusch, 2004). As this approach focuses on the evaluation of the delivered experience, it fails to sufficiently acknowledge the active role of tourists as value co-creators in the tourism context.

To highlight the active role of tourists, the "value in" perspective has emerged, building on S-D logic, which posits that "co-creation is about joint creation of value by the company and the customer" (Prahalad \& Ramaswamy, 2004: 8). Customer values are collaboratively created between customers and service providers. It is through high quality interactions that unique experiences are co-created (Binkhorst \& Dekker, 2009; Grönroos, 2011). However, the dominant S-D approach is viewed from the service providers' perspective without fully recognizing the growing power of consumers (Heinonen et al., 2010) and the desire for an interactive and authentic tourism experience (Campos et al., 2018)

Recognizing the limitations of S-D logic and the experiential nature of tourism, C-D logic has emerged (Heinonen et al., 2010; Heinonen \& Strandvik, 2015). C-D logic emphasizes "how customers embed service in their processes rather than how firms provide service to customers" (Heinonen \& Strandvik, 2015: 472). In contrast to previous value co-creation approaches, C-D logic focuses on customers' intentions and resultant experiences. In this vein, value emerges when services become "embedded in the customer's context, activities, practices and experiences together with the service company's activities" (Heinonen et al., 2010; 537). According to C-D 
logic, value is a multi-dimensional construct that originates in lived and imagined experience, and it is both individually and socially constructed (Helkkula, Kelleher \& Pihlstrom, 2012). C-D logic does not suggest that the role of the service provider is completely eliminated. Rather, it proposes a broader role for companies in supporting consumers' value creation (Heinonen et al., 2010). Such an approach is in line with the belief that service should facilitate value for customers (Grönroos, 2011).

Among the existing co-creation studies, S-D logic is still dominant (Campos et al., 2018; Wong \& Lai, 2018). C-D logic has primarily been discussed in terms of its conceptualization and implications (e.g., Heinonen et al., 2010; Heinonen \& Strandvik, 2015; Rihova et al., 2015). A growing number of empirical studies have focused on C-D logic. For example, Tynan, McKechnie \& Hartley (2014) adopted a phenomenological approach to understand how individuals make sense of their participation in lived car consumption experience. Rihova et al., (2018) identified different customer-to-customer co-creation practices in tourism consumption. While the concept of co-creation has been recognized as a competitive advantage for the service industry, including tourism, many researchers argue that co-creation in tourism is still in the early stages (Harkison, 2018). In particular, researchers argue that it is still unclear to what extent co-creation affects the psychological process of individuals and creates competitive advantages for the industry.

C-D logic plays a crucial role in festivals. Among all types of tourism experiences, the festival experience has been strongly associated with the idea that experiential value is coconstructed. Festivals are held at particular points in time and occur for a variety of reasons, from non-routine occasions to entertaining and celebrating groups of people (Shong \& Parry, 2004). Numerous studies of festivals and events have found that festival visitors are the co-creators of their festival experience (e.g., Getz, 2010; Getz \& Page, 2016). Sometimes, they have become the sole creators of value in the festival context (Rihova et al., 2015). Value is socially constructed in C-D logic (Helkkula et al., 2012). According to Rihova et al. (2018), customer-tocustomer interactions represent a crucial social value for tourists. Adopting C-D logic, they argue that as tourism consumption involves interactions with peers and significant others or simply being co-present as part of a larger collective, the social value of such encounters is formed in the process of tourists' customer-to-customer co-creation. In a study of five UK-based festivals, they identified that values were formed through customers' interactive social practices. Involving 
visitors in shared and interactive activities that are aligned with their interests and capture their attention is very important to creating an engaging festival atmosphere and visitors' shared event identity (Davis, 2017). While the fact that customer-to-customer co-creation festival experiences cannot be predesigned motivates researchers to search for a more customer-focused approach (Rihova et al., 2015), existing studies have only illustrated the importance and practices of customer-to-customer co-creation (e.g., Rihova et al., 2018) without empirically exploring its role in customers' evaluation of such experience.

\subsection{Satisfaction with co-creation experience and festival evaluation}

Satisfaction is an important concept to understand in the co-creation festival context. A number of studies show that understanding tourist satisfaction is essential to a successful strategy due to its profound impacts on both tourist consumption and future intention (e.g., Prebensen, Vitters $\varnothing$ \& Dahl, 2013; Mathis et al., 2016). It has often been conceptualized as a positive reaction to a favorable appraisal of a shared consumption experience (Babin \& Griffin, 1998). Hence, satisfaction is often viewed as an outcome of the perceived value of travel experience (Prebensen, Vitters $\varnothing$ \& Dahl, 2013). There is an increasingly important trend towards linking cocreation of an experience and satisfaction with travel experience due to the recognition that cocreation can increase travel satisfaction (Mathis et al., 2016). Studies have shown that consumer satisfaction with a service results from greater participation in co-creation (e.g., Campos et al., 2018; Mathis et al., 2016). In studying UK festivals, Rihova et al., (2018) found that festival goers are essential for festival experience as their interactions inseparately linked with the experience; further, their active participation in customer-to-customer value co-creation eventually enhances their own satisfaction. Similarly, other studies have also found that festival satisfaction largely depends on the dominant customers' interactions, i.e. between festival attendees and service providers (Davis, 2017; Rihova et al., 2015). Festivals become social spaces where continuous interactions with festival providers and other visitors become crucial indicators of the event's success (e.g., Getz, 2010). It is the potential of co-creation of an experience in influencing satisfaction with the festival experience that leads to our hypothesis:

H1: Satisfaction with the co-creation experience is positively associated with festival satisfaction. 
Satisfaction is a determinant of consumer retention behavior, which suggests that building satisfaction plays a crucial role in establishing long-term relationships with consumers (Babin \& Griffin, 1998; Baker \& Crompton, 2000; Grappi \& Montanari, 2011). In the festival context, satisfaction with festival visitors' customer-to-customer co-creation facilitates unique festival experiences and motivates re-patronizing behavior (e.g., Grappi \& Montanari, 2011; Lee et al., 2012; Rihova et al., 2015). Studies have shown that festival satisfaction is positively associated with festival re-patronizing intention (e.g., Grappi \& Montanairi, 2011; Lee et al., 2012). This suggests that when festival attendees are satisfied with the festival experience, they are more likely to re-patronize the specific festival due to the unique experience they had, compared with other festivals. Hence, the following hypotheses are proposed:

H2: Satisfaction with the co-creation experience is positively associated with festival repatronizing intention.

H3: Festival satisfaction is positively associated with festival re-patronizing intention.

\subsection{Co-creation experience, place attachment and festival evaluation}

Although both co-creation and place attachment have extensive histories of being applied to different marketing issues, there is a lack of theoretical proposition connecting them in the literature. While co-creation requires active involvement of customer (Auh, Bell, McLeod, \& Shih, 2007), the Involvement—commitment theory can provide theoretical implications (Beatty, Homer, \& Kahle, 1988). The theory suggests that a person's satisfaction with the involvement process will be translated to his/her psychological attachment to a brand because the process adds value to him/her. Generalizing this theoretical argument to our study, it should be reasonable to conjecture that satisfaction with the co-creation experience (satisfaction with the involvement process) is positively associated with place attachment (commitment).

Perhaps owing to the lack of theoretical foundation, little empirical work has examined the relationship between co-creation experience and place attachment, especially in the festival context. Those few studies that have touched on the relationship between co-creation and place attachment have resulted in relatively ambiguous explanations. Suntikul and Jachna (2016), for example, integrated tourists' physical cultural heritage experiences with the co-creation concept, highlighting the experience with the physical tourism site, not merely as the setting, but as a 
fundamental dimension of the tourism experience. Even though the study failed to demonstrate a linear relationship between co-creation and place attachment, it did show how the co-created tourism experience is inseparable from the psychological attachment to a place (i.e., place identity and place dependence). A key asset of any festival is its ability to offer a distinct temporary environment (Richards \& Wilson, 2006). Other studies have shown that emotional attachment to a destination is associated with the meaning and identity of a place. This is not only derived from its physical characteristics, but from people's interactions with it (Davis, 2017; Lee, 2001; Ujang, 2017). It is the co-creating experience that makes the festive distinctive (Rihova et al., 2015).

Festivals, especially cultural festivals, are often designed to connect a place with a particular set of values and meanings (Quinn, 2003). Thus, cultural festivals are often regarded as an important element in promoting a place or destination (Davis, 2017; Getz, 2010). Acknowledging that place attachment is the primary mechanism in constructing visitor relationships with festival environments (Davis, 2017; Lee et al., 2012). Rooted in geography and environmental psychology, place attachment is the psychological bonding people develop toward places (e.g., Hernández et al., 2007; Lee et al., 2012; Ujang, 2017). People become attached to destinations when they associate place-related meanings with social interactions occurring at the destination (Milligan, 1998; Lee 2001).

Previous studies have routinely conceptualized place attachment as a multidimensional construct mainly consisting of place dependence and place identity (e.g., Gu \& Ryan, 2008; Hernández et al., 2007; Lee et al., 2012; Suntikul \& Jachna, 2016). Some studies have also included social ties that bind individuals to the landscape to understand place attachment; those studies have mainly used social ties to understand residents' long term social investment within their neighborhood area (eg., Hernández et al., 2007). As this study aims to understand locals’ and tourists' experiences, such aspects become less relevant in the tourism context (Suntikul \& Jachna, 2016). Here, place attachment is embodied in an area's physical characteristics and is related to specific activity needs (Su, Cheng \& Hung, 2011). Place dependence refers to the connections that are specifically based on destination activities that fulfill people's individual goals (Gu \& Ryan, 2008). In other words, place dependence rests upon cognitive evaluation of whether the goal has been achieved. Alternatively, place identity is based on the broadly conceived perception of place and often involves locating the individual self within a particular 
spatial setting (Jorgensen \& Stedman, 2001). Just as the word identity often indicates a sense of distinctiveness and uniqueness, place identity has become an important concept in understanding the relationship between a place's distinctiveness and the sense of self (Twigger \& Uzzell, 1996). So, place identity reflects the emotional attachment to a place (Raymond, Brown, \& Weber, 2010). In sum, the two dimensions count in both the cognitive and emotional attachment to a place. Referring to the aforementioned Involvement—commitment theory, commitment has the dimensions of cognitive assessment of the benefits for maintaining relationship and emotional bonding with the relationship (Arriaga \& Agnew, 2001), which echo place dependence and place identity. Therefore, we hypothesize that satisfaction with the co-creation experience (involvement) has positive relationships with the place attachment dimensions:

H4a: Satisfaction with the co-creation experience is positively associated with place identity. H4b: Satisfaction with the co-creation experience is positively associated with place dependence.

The positive effects of satisfaction on place attachment have been tested in different studies. For example, Ramkissoon, Smith and Kneebone (2014) found that visitor satisfaction was a good predictor of place attachment in national parks. Lee et al., (2012) found that festival satisfaction was positively associated with place attachment. Hence, attending a festival may enhance psychological bonding with the festival's host destination. In this vein, the following hypotheses are developed:

H5a: Festival satisfaction is positively associated with place identity.

H5b: Festival satisfaction is positively associated with place dependence.

Place attachment is often regarded as an important construct for understanding the psychological bonding of an individual to a physical landscape (e.g., Hernández et al., 2007). Many studies have demonstrated that the stronger the psychological bonding with a destination the greater the individual's intention to revisit (e.g., Ramkissoon et al., 2014; Suntikul \& Jachna, 2016). In the same way, Lee et al., (2012) demonstrated that place attachment generated in the festival setting positively influences individuals' behavioral intentions. Hence, the following hypotheses are developed: 
H6a: Place identity is positively associated with festival re-patronizing intention.

H6b: Place dependence is positively associated with festival re-patronizing intention.

Previous studies have found that the relationships between satisfaction and co-creation, and satisfaction and the impact of a vacation on life overall are mediated by satisfaction with the vacation experience (Mathis et al., 2016). Festival satisfaction has proven to be a mediator between service quality and behavioral intention (e.g., Cole \& Illum, 2006). Within the festival tourism context, the quality of a festival is largely influenced by customer-to-customer cocreation. It is thus reasonable to propose that festival satisfaction mediates the relationship between co-creation and re-patronizing intention.

Place attachment as a mediator has been increasingly recognized in tourism research (e.g., Kil et al., 2012; Lee et al., 2012). To highlight psychological attachment to a place it is critical to understand behavioral intention. Accordingly, it is important to examine the mediating effects of place attachment (e.g., Lee et al., 2012). Suntikul \& Jachna (2016:278) argue that both cocreation experience and place attachment address “essential aspects of tourists' emotional engagement with tourism experience" and they are correlated. Furthermore, Su et al., (2018) argue that place attachment is a significant mediator in the relationship between satisfaction with sport events attributes and revisit intention According to $\mathrm{C}-\mathrm{D}$ logic, co-creating social value in festivals is increasingly considered an important festival attribute and is embedded in a specific environment (Rihova et al., 2018). As a result, place attachment is critical to influence festival co-experience and festival evaluation (Davis, 2017; Rihova et al., 2015). These arguments hint that festival satisfaction and place attachment have mediation roles between co-creation experience and re-patronizing intention.

The Involvement - commitment theory has been extended to loyalty behavior alongside the argument that commitment nurtures resistance to choose the alternatives (Pritchard, Havitz, \& Howard, 1999). Empirical evidence on involvement - commitment-loyalty has been reported in leisure studies (Bee \& Havitz, 2010; Chang \& Gibson, 2015; Iwasaki \& Havitz, 2004), which lends support to the mediating relationship of co-creation experience-place attachment-repatronizing intention. However, this theoretical argument does not perfectly fit this study because of the contexts of festival and place. This pitfall can be addressed by incorporating the 
mediating role of festival satisfaction. Co-creation is a component contributing to the overall festival experience (festival context), whereas place attachment is a construct focusing on the place (place context). Theory suggests that transaction-specific satisfaction (e.g., satisfaction with the co-creation experience) is transferrable to satisfaction with the parent contexts (e.g., festival and place) which in turn drives repurchase intention (e.g., festival re-patronizing intention) (Jones \& Suh, 2000). As such, it should be theoretically reasonable to conjecture that satisfaction with the co-creation experience will lead to festival satisfaction, then place attachment, and eventually re-patronizing intention. Accordingly, we propose the following serial mediation hypotheses:

H7a: The relationship between satisfaction with co-creation experience and festival repatronizing intention is serially mediated by festival satisfaction and place identity.

H7b: The relationship between satisfaction with co-creation experience and festival repatronizing intention is serially mediated by festival satisfaction and place dependence.

\subsection{Differences between tourists and residents}

Previous studies on place attachment have often assumed that locals and tourists hold distinctive attachments to destinations. Residents of places inevitably form stronger attachments than temporary visitors (e.g., Gu \& Ryan, 2008; Hernández et al., 2007; Yolal et al., 2016; Chi, Ouyang \& Xu, 2018). Among these studies, residents' place attachment is often examined to understand the social implication of events in host destinations (e.g, Chi et al., 2018) and inevitably paid less attention from the tourists' side. Co-creation studies, however, have often treated festival goers collectively in terms of festival co-creation, without identifying the differences between local and non-local visitors (e.g., Rihova et al., 2015). In explaining the value of co-creation to residents' life satisfaction at a given destination, Lin, Chen \& Filieri (2017) acknowledged the importance of tourists and residents' interactions with the destination. Nonetheless, the inclusion of only residents in their sample, suggests that understanding the cocreation needs of both residents and tourists requires a broader sample that includes both parties. To further investigate the differences between residents and tourists, this study proposes these different moderators in the proposed festival evaluation model. 
H8: Type of respondents (tourists versus residents) moderates the positive relationships between (a) satisfaction with the co-creation experience and festival re-patronizing intention; (b) satisfaction with the co-creation experience and place dependence; (c) satisfaction with the cocreation experience and festival satisfaction; (d) satisfaction with the co-creation experience and place identity; (e) festival satisfaction and place dependence; (f) festival satisfaction and festival re-patronizing intention; (g) festival satisfaction and place identity; (h) place identity and festival re-patronizing intention, and (i) place dependence and festival re-patronizing intention. Specifically, the relationships are different for tourists and residents.

\section{METHODS}

In this study, the "Macao International Parade," also known as the "Parade through Macao, Latin City" was chosen as the study site. Macao is a famous destination in Asia, with 32,610,506 tourist arrivals in 2017. Nearly 90\% of Macao's tourists come from the Greater China region (mainland China, Hong Kong and Taiwan) (DSEC, 2018). The one-day cultural parade in Macao began in 2011 and attracted more than 130,000 festival visitors. Thereafter, the festival became one of the city's major events to showcase the its ambience and cultural integration, and promote cultural and artistic interactions among local and international visitors. The parade starts at the World Heritage site Ruins of St. Paul and ends with a celebration at Sai Van Lake Square, traversing important heritage sites within the city (Cultural Affairs Bureau, 2017). The performers of this festival consist of more than 1,300 artists from 49 local groups and 15 international groups and thus shared consumption and interaction are arguably important to this festival. The pictures shown below capture the festival's popularity.

Macao International Parade aims to promote the multicultural aspect of the city and provide a platform for interactions between different cultures (MGTO, 2018) and thus the route of the Parade along the narrow streets allowed close interaction not only among festival attendees but between these attendees and performers. Two authors have attended this festival in previous years. Based on their observations, these interactive activities between attendees and performers in the festival include chatting regarding the performances, selfies and dancing. Since many of the performers were from the local groups, their families and friends as local attendees also came 
to celebrate with them. Many attendees walked with the performing groups which together forms part of the parade.

\section{Macao International Parade}
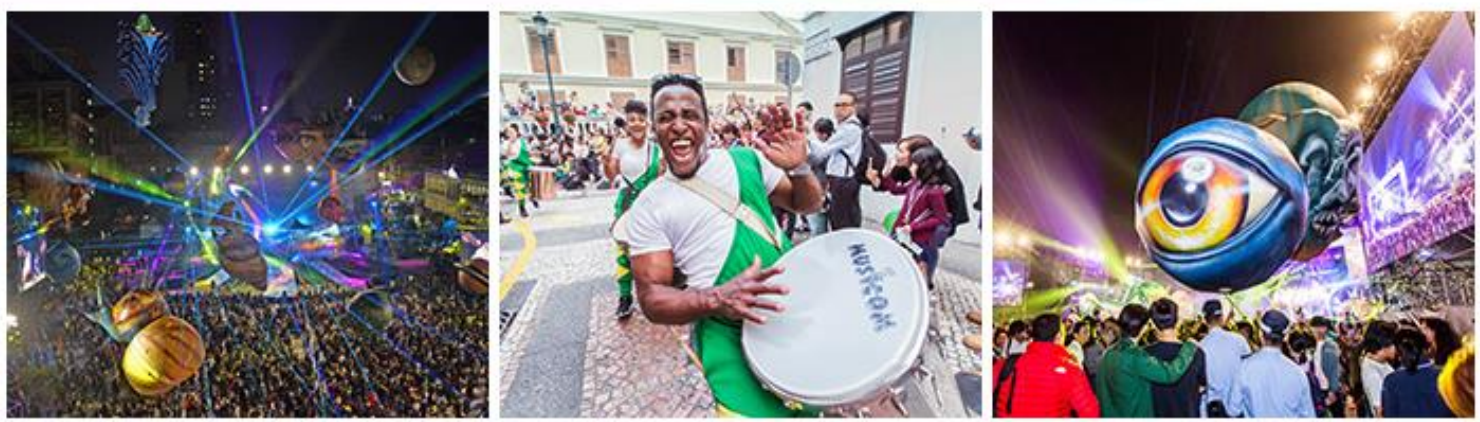

Figure 2: Macao International Parade (MGTO, 2018)

In relation to this study, a positivist approach is dominant and it is possible to uncover the scale of the phenomena explored (Bryman, 2012), namely place attachment, satisfaction with cocreation and festival evaluation. Yet, understanding customer-to-customer co-creation is still in a developing stage (Campos et al., 2018). Among those limited studies, which adopted C-D logic, the importance of context is often highlighted (Rihova et al., 2018). Thus before the main quantitative data collection, semi-structured interviews with previous festival goers $(n=10)$ and festival organizers $(n=5)$ were conducted on November, 2017. Despite the involvement of the indepth interview, the study remains positivist as it followed an essentialist epistemological approach to achieve better scale verification prior to the main stage (Bryman, 2012). This approach is widely used in tourism research (e.g., Biran et al., 2014). This pre-stage focuses on individuals' festival experience and their intention to participate in customer-to-customer cocreation. Purposive sampling has the advantage of selecting individuals on the basis of their being able to provide information-rich data with regard to a particular phenomenon (Cresswell, 2007). The final sample included an equal number of male and females informants, aged from 18 to 60 , with a college and above education. This exploratory stage provided contextual data and informed the main quantitative survey design.

The survey was designed to test the research model in Figure 1. All of the measures of this study's constructs were developed from the literature with reference to the festival context. All of the items used for hypothesis testing are shown in Table 1. A 5-point Likert scale (ranging 
from 1: strongly disagree to 5: strongly agree) was deployed to measure the items. Based on the qualitative stage and previous literature (e.g., Mathis et al., 2012; Rihova et al., 2015), the measure of satisfaction with the co-creation experience at festivals was developed. Here, customer-to-customer co-creation in festivals focuses on customers' intentions and the resultant experience. While the majority of the previous studies are largely concerned with co-creation among festival goers (e.g.,Rihova et al., 2018), our interviews and observations were also concerned with informants' co-creation experience with the performers. This is largely due to the fact that the Macao International Parade aims to promote the multicultural aspect of the city and provide a platform for interactions between different cultures (MGTO, 2018). As a result, local and international cultural groups are invited to promote the fusion culture and highlight Macao as a platform for interaction. As informants feel that co-creation with performers are embedded in their overall intention to fulfill their socio-cultural values in this particular festivals. A couple of informants in the pre-stage even regarded the performers as both tourists (international performers) and residents (local performers), who jointly create a hedonic festival experience. Hence, co-creation with performers was included. Here, each construct was taken from the literature but modified to suit the context of the study (Biran et al., 2014).

In other words, the co-creation experience was created through festival goers' interactions with performers and festival goers, and thus satisfaction with the co-creation experience was decomposed into two dimensions (lower-order constructs: LOCs): the co-creation experience with the performers and co-creation experience with other festival goers. Because the performers and other festival goers were two separate counterparts, there was no assumption that experiences with the performers would be different from experiences with the other festival goers. Technically, there were no grounds for assuming that satisfaction stemming from the performers would be correlated with the things that aroused the other festival goers. Therefore, the two dimensions were treated as formative LOCs and a reflective-formative hierarchical component model was constructed to measure satisfaction with the co-creation experience (see the shaded part in Figure 1).

Place dependence and place identity were measured using three items each, adapted from Lee et al., (2012) and Suntikul \& Jachna (2016). The original scale developed by Williams and Roggenbuck (1989) was also taken into consideration and place attachment was measured by two-dimension, place identity and place dependence. Festival satisfaction was operationalized 
using three items borrowed from other festival studies (Grappi \& Montanari, 2011; Lee et al., 2012). Festival re-patronizing intention was measured by four items borrowed from Grappi and Montanari (2011) and Lee et al. (2012). To determine the type of respondent, those interviewed were asked if they were tourists or residents. They had previously been asked about their gender, age, and education.

A street-intercept survey was conducted on December 17, 2017, the festival day, to collect the data. To become qualified to complete the survey for this study, the respondents were required to be 18 or older and were asked their age at the beginning of the survey. Twenty-two experienced and trained interviewers were assigned to different locations along the route where the festival goers gathered. Seven supervisors patrolled and monitored the interviewers to control the quality of data collection. Eventually, data from 473 responses were collected.

\section{Table 1. Outer loadings and cross loadings of reflective constructs}




\begin{tabular}{|c|c|c|c|c|c|c|c|}
\hline Items & & $\mathrm{CoCP}$ & CoCG & FS & PI & PD & FR \\
\hline $\begin{array}{l}\mathrm{CoCP} \\
1\end{array}$ & $\begin{array}{l}\text { I felt comfortable interacting with } \\
\text { the performer(s) during this } \\
\text { festival. }\end{array}$ & 0.890 & 0.515 & 0.458 & 0.407 & 0.327 & 0.404 \\
\hline $\begin{array}{l}\mathrm{CoCP} \\
2\end{array}$ & $\begin{array}{l}\text { The setting of the festival allows } \\
\text { me to effectively interact with the } \\
\text { performer(s). }\end{array}$ & 0.900 & 0.578 & 0.450 & 0.322 & 0.312 & 0.388 \\
\hline $\begin{array}{l}\text { CoCG } \\
1\end{array}$ & $\begin{array}{l}\text { I felt comfortable interacting with } \\
\text { other festival goers during the } \\
\text { festival. }\end{array}$ & 0.524 & 0.879 & 0.380 & 0.383 & 0.373 & 0.347 \\
\hline $\begin{array}{l}\text { CoCG } \\
2\end{array}$ & $\begin{array}{l}\text { The setting of the festival allowed } \\
\text { me to effectively interact with } \\
\text { other festival goers. }\end{array}$ & 0.553 & 0.885 & 0.361 & 0.416 & 0.399 & 0.351 \\
\hline FS1 & $\begin{array}{l}\text { I was satisfied with my visit to } \\
\text { this festival. }\end{array}$ & 0.484 & 0.405 & 0.923 & 0.484 & 0.443 & 0.708 \\
\hline FS2 & I felt very good about this festival. & 0.459 & 0.376 & 0.937 & 0.502 & 0.437 & 0.704 \\
\hline FS3 & I was satisfied with this festival. & 0.465 & 0.386 & 0.919 & 0.497 & 0.465 & 0.712 \\
\hline PI1 & Macao says a lot about who I am. & 0.336 & 0.318 & 0.369 & 0.687 & 0.459 & 0.400 \\
\hline PI2 & Macao is very special to me. & 0.344 & 0.390 & 0.448 & 0.812 & 0.569 & 0.422 \\
\hline PI3 & I identify strongly with Macao. & 0.316 & 0.328 & 0.451 & 0.841 & 0.590 & 0.416 \\
\hline PI4 & I am very attached to Macao. & 0.292 & 0.366 & 0.407 & 0.833 & 0.599 & 0.420 \\
\hline PI5 & Macao means a lot to me. & 0.287 & 0.390 & 0.421 & 0.819 & 0.603 & 0.413 \\
\hline PI6 & $\begin{array}{l}\text { I have a lot of fond memories of } \\
\text { Macao. }\end{array}$ & 0.364 & 0.370 & 0.449 & 0.782 & 0.627 & 0.452 \\
\hline PD1 & $\begin{array}{l}\text { When I've been away from } \\
\text { Macao for a while, I really want } \\
\text { to come back. }\end{array}$ & 0.296 & 0.356 & 0.365 & 0.602 & 0.759 & 0.388 \\
\hline PD2 & $\begin{array}{l}\text { For what I like to do, no other } \\
\text { places can compare to Macao. }\end{array}$ & 0.287 & 0.358 & 0.319 & 0.521 & 0.826 & 0.385 \\
\hline PD3 & $\begin{array}{l}\text { I wouldn't substitute any other } \\
\text { places for doing the types of } \\
\text { things I do in Macao. }\end{array}$ & 0.251 & 0.338 & 0.323 & 0.505 & 0.811 & 0.403 \\
\hline PD4 & $\begin{array}{l}\text { I would personally recommend } \\
\text { Macao to others. }\end{array}$ & 0.294 & 0.340 & 0.493 & 0.643 & 0.783 & 0.564 \\
\hline FR1 & $\begin{array}{l}\text { I will visit this festival again next } \\
\text { time. }\end{array}$ & 0.365 & 0.349 & 0.645 & 0.458 & 0.485 & 0.859 \\
\hline FR2 & $\begin{array}{l}\text { I will recommend the festival to } \\
\text { my friends and family. }\end{array}$ & 0.456 & 0.380 & 0.743 & 0.504 & 0.531 & 0.936 \\
\hline FR3 & $\begin{array}{l}\text { I will encourage my friends and } \\
\text { family to visit the festival next } \\
\text { time. }\end{array}$ & 0.385 & 0.348 & 0.709 & 0.473 & 0.510 & 0.922 \\
\hline FR4 & $\begin{array}{l}\text { I will say positive things to other } \\
\text { people. }\end{array}$ & 0.396 & 0.358 & 0.675 & 0.483 & 0.507 & 0.912 \\
\hline
\end{tabular}

Notes: Values in boldface are outer loadings, whereas others are cross-loadings; CoCP $=$ Co-creation Experience with Performers; CoCG $=$ Co-creation Experience with Other Goers; FS = Festival Satisfaction; PI = Place Identity; $\mathrm{PD}=$ Place Dependence; FR = Festival Re-patronizing Intention. 
Because it was expected that most of the respondents would only read Chinese, a bilingual survey instrument with both English and Chinese was developed. To ensure semantic equivalence, translation and back-translation were conducted. The English questionnaire was first translated into Chinese by a person proficient in both written English and Chinese. The Chinese instrument was reviewed by the first author to ensure that the language used was adequate. Thereafter, a third person translated the Chinese questionnaire back into English. All of the investigators concluded that the Chinese version was semantically equivalent to the English version. A pilot test was conducted among ten respondents for their comments on any language ambiguities in the questionnaire. All of them found it adequate and we concluded that the instrument was suitable for our main study.

\section{ANALYSIS AND RESULTS}

\subsection{Data cleaning and respondent profiles}

Among the 473 collected responses, 23 contained missing values and were thus excluded from subsequent analyses. Among the remaining 450 responses, six outlier cases were identified given that their standardized values in certain variables were out of the range of -4 to 4 (Mertler \& Vannatta, 2010). In the end, 444 cases were retained.

Table 2 shows the respondents' profiles. Almost 60\% were female (female: $n=263$, proportion $=59.2 \%)$. Many were young, with roughly $45 \%$ being $18-24(n=196$, proportion $=$ $44.1 \%)$ and almost $20 \%$ being 25-29 $(n=86$, proportion $=19.4 \%)$. The respondents tended to achieve high education with over $60 \%$ having a Bachelor's degree or above $(n=275$, proportion $=61.9 \%$ ). There were more residents than tourist respondents with the former recording 270 responses (proportion 60.8\%).

Table 2. Profile of the respondents $(n=444)$ 


\begin{tabular}{|c|c|c|}
\hline Characteristics & Number & Percentage \\
\hline \multicolumn{3}{|l|}{ Gender } \\
\hline Male & 181 & $40.8 \%$ \\
\hline Female & 263 & $59.2 \%$ \\
\hline \multicolumn{3}{|l|}{ Age } \\
\hline $18-24$ & 196 & $44.1 \%$ \\
\hline $25-29$ & 86 & $19.4 \%$ \\
\hline $30-34$ & 47 & $10.6 \%$ \\
\hline $35-39$ & 45 & $10.1 \%$ \\
\hline $40-44$ & 30 & $6.8 \%$ \\
\hline $45-49$ & 11 & $2.5 \%$ \\
\hline $50-54$ & 13 & $2.9 \%$ \\
\hline $55-59$ & 5 & $1.1 \%$ \\
\hline $60-64$ & 8 & $1.8 \%$ \\
\hline 65 or above & 3 & $0.7 \%$ \\
\hline \multicolumn{3}{|l|}{ Education } \\
\hline Primary or below & 16 & $3.6 \%$ \\
\hline High school & 153 & $34.5 \%$ \\
\hline Bachelor's degree & 248 & $55.9 \%$ \\
\hline Master's degree or above & 27 & $6.1 \%$ \\
\hline \multicolumn{3}{|l|}{ Type of respondents } \\
\hline Tourist & 174 & $39.2 \%$ \\
\hline Resident & 270 & $60.8 \%$ \\
\hline
\end{tabular}

\subsection{Measurement model}

Partial least square structural equation modeling (PLS-SEM) was used to examine the hypotheses. Data normality was not a concern due to the bootstrapping process in PLS-SEM. Considering the sample size, the recommendations stemmed from different methods, including the largest number of structural paths pointing to a construct (Hair, Hult, Ringle, \& Sarstedt, 2014), power analysis (Hair, Ringle, \& Sarstedt, 2017), and the inverse square root method (Kock \& Hadaya, 2018). Four hundred forty-four samples were enough to perform PLS-SEM. Additionally, PLS-SEM allowed the model to be examined with formative constructs (Fong, Fong, \& Law, 2016).

To assess the reliability and validity of the reflective measures, several criteria were considered. According to Hair et al. (2017), the outer loading values needed to be above 0.4. Table 1 shows that the smallest outer loading value was 0.687 (Item PI1). The reliability of the measures was demonstrated by Cronbach's Alphas, rho_A values, and composite reliability 
values exceeding 0.7. Convergent validity was attained because the average variance extracted (AVE) values were greater than 0.5. To assess discriminant validity, we checked (1) if the outer loading values on the constructs were greater than their cross-loading values on other constructs (see Table 1), and (2) if the AVE values of constructs were greater than their squared correlations with other constructs (see Table 3). The results showed that these two criteria were met. We further assessed discriminant validity using the Heterotrait-Monotrait Ratio (HTMT) criteria. All HTMT values were less than 0.9 (Henseler, Ringle, \& Sarstedt, 2015) and all confidence interval bias corrected HTMT ranges did not include 1 (see Table 4).

Table 3. Assessment of reliability and validity of reflective constructs

\begin{tabular}{lllllll}
\hline $\begin{array}{l}\text { Squared Correlation between } \\
\text { Constructs }\end{array}$ & CoCP & CoCG & FS & PI & PD & FR \\
\hline CoCP & 1.000 & & & & & \\
CoCG & 0.373 & 1.000 & & & & \\
FS & 0.257 & 0.176 & 1.000 & & & \\
PI & 0.165 & 0.205 & 0.285 & 1.000 & & \\
PD & 0.127 & 0.192 & 0.235 & 0.524 & 1.000 & \\
FR & 0.196 & 0.156 & 0.584 & 0.280 & 0.314 & 1.000 \\
\hline Average Variance Extracted & 0.801 & 0.778 & 0.858 & 0.636 & 0.632 & 0.824 \\
\hline Composite Reliability & 0.890 & 0.875 & 0.948 & 0.912 & 0.873 & 0.949 \\
\hline rho_A & 0.753 & 0.715 & 0.917 & 0.886 & 0.815 & 0.931 \\
\hline Cronbach's Alpha & 0.752 & 0.715 & 0.917 & 0.884 & 0.808 & 0.929 \\
\hline
\end{tabular}

Notes: $\mathrm{CoCP}=\mathrm{Co}$-creation experience with performers; $\mathrm{CoCG}=\mathrm{Co}$-creation experience with other festival goers; FS = Festival satisfaction; PI = Place identity; PD = Place dependence; FR = Festival re-patronizing intention. 
Table 4. HTMT results for reflective constructs

\begin{tabular}{|c|c|c|c|c|c|}
\hline & $\mathrm{CoCG}$ & FS & PI & PD & FR \\
\hline $\mathrm{CoCP}$ & $\begin{array}{l}0.832 \mathrm{CI}_{.900} \\
{[0.708,} \\
0.932]\end{array}$ & $\begin{array}{l}0.611 \mathrm{CI}_{900} \\
{[0.495,0.707]}\end{array}$ & $\begin{array}{l}0.499 \mathrm{CI}_{.900} \\
{[0.374} \\
0.619]\end{array}$ & $\begin{array}{l}0.455 \mathrm{CI}_{.900} \\
{[0.320,} \\
0.581]\end{array}$ & $\begin{array}{l}0.528 \mathrm{CI}_{.900} \\
{[0.407,0.638]}\end{array}$ \\
\hline $\mathrm{CoCG}$ & & $\begin{array}{l}0.519 \mathrm{CI}_{.900} \\
{[0.390,0.634]}\end{array}$ & $\begin{array}{l}0.569 \mathrm{CI}_{.900} \\
{[0.461} \\
0.669]\end{array}$ & $\begin{array}{l}0.574 \mathrm{CI}_{.900} \\
{[0.453,} \\
0.683]\end{array}$ & $\begin{array}{l}0.485 \mathrm{CI}_{.900} \\
{[0.366,0.593]}\end{array}$ \\
\hline FS & & & $\begin{array}{l}0.592 \mathrm{CI}_{900} \\
{[0.486,0.68]}\end{array}$ & $\begin{array}{l}0.547 \mathrm{CI}_{.900} \\
{[0.438} \\
0.641]\end{array}$ & $\begin{array}{l}0.827 \mathrm{CI}_{900} \\
{[0.767,0.879]}\end{array}$ \\
\hline PI & & & & $\begin{array}{l}0.842 \mathrm{CI}_{.900} \\
{[0.780,} \\
0.895]\end{array}$ & $\begin{array}{l}0.583 \mathrm{CI}_{.900} \\
{[0.491,0.664]}\end{array}$ \\
\hline PD & & & & & $\begin{array}{l}0.630 \mathrm{CI}_{.900} \\
{[0.544,0.708]}\end{array}$ \\
\hline
\end{tabular}

Notes: $\mathrm{CoCP}=\mathrm{Co}$-creation experience with performers; $\mathrm{CoCG}=\mathrm{Co}$-creation experience with other festival goers; FS = Festival satisfaction; PI = Place identity; PD = Place dependence; FR = Festival re-patronizing intention.

To assess the validity of the formative model, we first checked for a multicollinearity issue. The variance inflation factors of the co-creation experience with performers (CoC_Perf) and the co-creation experience with other festival goers (CoC_Goer) were both less than 5 (1.595), indicating the lack of a multicollinearity issue. Because the relationships between these two constructs and satisfaction with the co-creation experience (SCoC) were close to each other and statistically significant (CoC_Perf $\rightarrow \mathrm{SCoC}=0.567, p=.000$; CoC_Goer $\rightarrow \mathrm{SCoC}=0.547, p$ $=.000)$, the formative constructs were deemed relevant and significant.

\subsection{Common method bias}

To assess whether the measures were threatened by common method bias, we initially performed Harman's Single-factor Test using factor analysis without rotation. Four factors were generated, with the first factor explaining $45.46 \%$ of the variance (less than 50\%), signaling that common method bias was not a concern in this study (Zhou et al., 2016). We then took a more rigorous approach called the unmeasured latent market construct (ULMC) method to assess common method bias (Fong, Lam, \& Law, 2017). The results showed that (1) only a few method factor loadings were statistically significant; (2) the substantive variances of the indicators largely exceed their method variances, and (3) the ratio of average substantive variance to average 
method variance was 59:1, which was greater than the ratio in Liang, Saraf, Hu, and Xue (2007) (42:1). The results added to the evidence that common method bias did not exist.

\subsection{Structural model}

Prior to reporting the hypotheses testing results, it was essential to assess whether a multicollinearity issue existed and what the predictive accuracy of the structural model was. The results showed that the largest variance inflation factors (VIF) value was below 5 so that the multicollinearity issue was not a concern. The blindfolding procedure (omission distance $=7$ ) revealed that all $Q^{2}$ values were above zero, indicating the satisfactory predictive accuracy of the structural model.

The hypotheses testing results are exhibited in Table 5 and Figure 2. Satisfaction with the co-creation experience was positively associated with festival satisfaction (coefficient $=0.517, p$ $=0.000$, effect size $f^{2}=0.366$ ), place identity (coefficient $=0.277, p=0.000$, effect size $f^{2}=$ 0.085 ), and place dependence (coefficient $=0.261, p=0.000$, effect size $f^{2}=0.070$ ). Festival satisfaction was positively related to place identity (coefficient $=0.391, p=0.000$, effect size $f^{2}=$ 0.170 ), place dependence (coefficient $=0.349, p=0.000$, effect size $f^{2}=0.125$ ), and festival repatronizing intention (coefficient $=0.629, p=0.000$, effect size $f^{2}=0.664$ ). These results supported H1, H3, H4a, H4b, H5a, and H5b.

Place dependence was positively associated with festival re-patronizing intention (coefficient $=0.237, p=0.000$, effect size $f^{2}=0.070$ ), but place identity was not related to festival re-patronizing intention (coefficient $=0.005, p=0.931$, effect size $f^{2}=0.000$ ). Thus, H6b, but not H6a, was supported. Further, H2 was not supported because satisfaction with the cocreation experience was not related to festival re-patronizing intention (coefficient $=0.035, p=$ 0.414 , effect size $f^{2}=0.002$ )

Among the two hypotheses for indirect effects, one was supported (H7b). Satisfaction with the co-creation experience was positively associated with re-patronizing intention due to the mediation effects of festival satisfaction and thereafter place dependence (coefficient $=0.043, p$ $=0.000)$. For H7a, in which place dependence was substituted with place identity, the indirect effect was not significant (coefficient $=0.001, p=0.465$ ). 
Table 5. Hypotheses testing results $(n=444)$

\begin{tabular}{|c|c|c|c|c|}
\hline Hypotheses & $\begin{array}{l}\text { Path } \\
\text { Coefficients }\end{array}$ & $t$-value & $p$-value & Bias Corrected CI \\
\hline $\mathrm{H} 1: \mathrm{SCoC} \rightarrow \mathrm{FS}$ & 0.517 & 11.575 & 0.000 & {$[0.419,0.595]$} \\
\hline $\mathrm{H} 2: \mathrm{SCoC} \rightarrow \mathrm{FR}$ & 0.035 & 0.817 & 0.414 & {$[-0.042,0.124]$} \\
\hline H3: FS $\rightarrow$ FR & 0.629 & 13.543 & 0.000 & {$[0.536,0.717]$} \\
\hline H4a: SCoC $\rightarrow$ PI & 0.277 & 5.466 & 0.000 & {$[0.180,0.377]$} \\
\hline $\mathrm{H} 4 \mathrm{~b}: \mathrm{SCoC} \rightarrow \mathrm{PD}$ & 0.261 & 4.811 & 0.000 & {$[0.158,0.367]$} \\
\hline H5a: FS $\rightarrow$ PI & 0.391 & 6.979 & 0.000 & {$[0.272,0.493]$} \\
\hline H5b: FS $\rightarrow$ PD & 0.349 & 6.084 & 0.000 & {$[0.234,0.454]$} \\
\hline H6a: PI $\rightarrow$ FR & 0.005 & 0.087 & 0.931 & {$[-0.108,0.110]$} \\
\hline H6b: PD $\rightarrow$ FR & 0.237 & 4.451 & 0.000 & {$[0.132,0.342]$} \\
\hline $\begin{array}{l}\text { H7a: } \mathrm{SCoC} \rightarrow \mathrm{FS} \rightarrow \mathrm{PI} \rightarrow> \\
\text { FR }\end{array}$ & 0.001 & 0.088 & 0.465 & {$[-0.018,0.020]$} \\
\hline $\begin{array}{l}\mathrm{H} 7 \mathrm{~b}: \mathrm{SCoC} \rightarrow \mathrm{FS} \rightarrow \mathrm{PD} \rightarrow> \\
\text { FR }\end{array}$ & 0.043 & 3.745 & 0.000 & {$[0.024,0.062]$} \\
\hline
\end{tabular}

Notes: $\mathrm{SCoC}=$ Satisfaction with co-creation experience; FS = Festival satisfaction; $\mathrm{PI}=$ Place identity; $\mathrm{PD}=$ Place dependence; FR = Festival re-patronizing intention.

Reflective-Formative Hierarchical Component Model

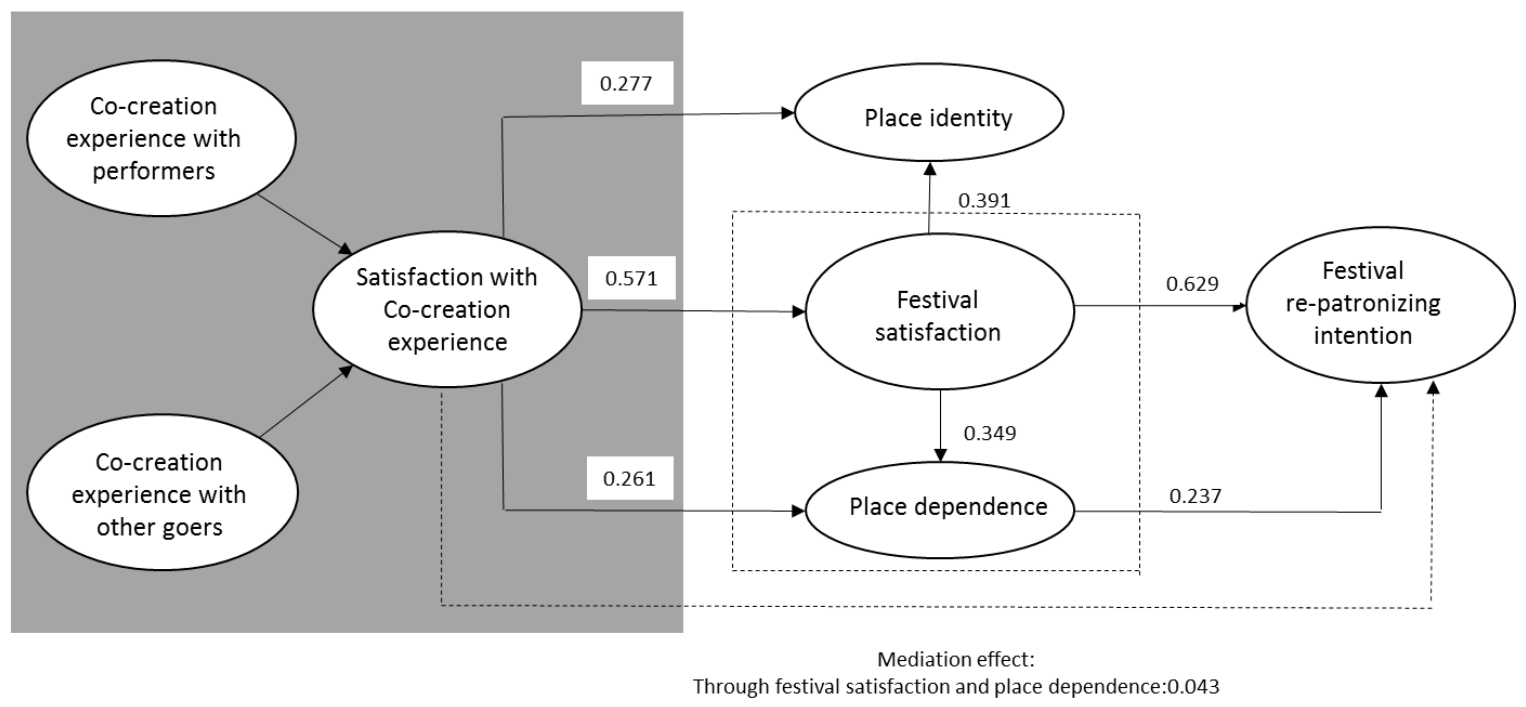

Figure 3. Model estimation results 


\subsection{The moderating role of type of respondents}

To examine Hypothesis 8, multi-group analysis was performed. According to Hair et al. (2018), the analysis is feasible if the sample size of the larger group is less than double the size of the smaller group. In this study, there were 270 resident respondents, which was less than double the size of the tourist respondents (i.e., $174 \times 2=348$ ). Therefore, the group sample size was adequate. To perform multi-group analysis, configural invariance and measurement invariance (at least partial) needed to be established.

To establish the configural invariance of the measures, the same indicators and algorithm settings were used in the analysis. Next, an examination of measurement invariance using the Measurement Invariance of Composite Model (MICOM) was conducted. The step 2 results of MICOM (see Table 6) showed that the correlation $c$ values were greater than the 5\% quantile of the empirical distribution of $c_{\mathrm{u}}$. Further evidence was drawn from the permutation $p$-values, indicating that the correlations were not significantly lower than $1(p>0.05)$. Taken together, the compositional invariance of the measurement was established.

\section{Table 6. MICOM Step 2 results}

\begin{tabular}{|c|c|c|c|c|}
\hline & $\begin{array}{l}\text { Correlation } \\
c\end{array}$ & $\begin{array}{l}5 \% \text { quantile } \\
\text { of the } \\
\text { empirical } \\
\text { distribution } \\
\text { of } c_{\mathrm{u}}\end{array}$ & p-value & $\begin{array}{l}\text { Compositional } \\
\text { invariance } \\
\text { established? }\end{array}$ \\
\hline $\begin{array}{lll}\text { Co-creation } & \text { experience } & \text { with } \\
\text { performers } & & \end{array}$ & 1.000 & 0.999 & 0.868 & Yes \\
\hline $\begin{array}{l}\text { Co-creation experience with other } \\
\text { festival goers }\end{array}$ & 1.000 & 0.999 & 0.974 & Yes \\
\hline Co-creation & 0.999 & 0.999 & 0.175 & Yes \\
\hline Festival satisfaction & 1.000 & 1.000 & 0.318 & Yes \\
\hline Place identity & 0.998 & 0.998 & 0.106 & Yes \\
\hline Place dependence & 0.998 & 0.995 & 0.359 & Yes \\
\hline Festival re-patronizing intention & 1.000 & 1.000 & 0.705 & Yes \\
\hline
\end{tabular}

Table 7 shows the step 3 results for MICOM. Equal mean values of the constructs were not found for place identity $(p=0.030)$ or place dependence $(p=0.039)$. However, their equal variances were established. Therefore, partial measurement invariance was established and multi-group analysis was feasible (Hair et al. 2018). 


\begin{tabular}{|c|c|c|c|c|}
\hline & $\begin{array}{l}\text { Difference of the } \\
\text { composite's mean } \\
\text { value }(=0)\end{array}$ & $\begin{array}{l}95 \% \text { confidence } \\
\text { interval }\end{array}$ & $\mathrm{p}$-value & $\begin{array}{l}\text { Equal } \\
\text { mean } \\
\text { values? }\end{array}$ \\
\hline $\begin{array}{l}\text { Co-creation experience with } \\
\text { performers }\end{array}$ & -0.036 & {$[-0.192 ; 0.192]$} & 0.713 & Yes \\
\hline $\begin{array}{l}\text { Co-creation experience with } \\
\text { other festival goers }\end{array}$ & -0.059 & {$[-0.197 ; 0.198]$} & 0.551 & Yes \\
\hline Co-creation & -0.053 & {$[-0.193 ; 0.201]$} & 0.579 & Yes \\
\hline Festival satisfaction & -0.183 & {$[-0.195 ; 0.188]$} & 0.059 & Yes \\
\hline Place identity & 0.209 & {$[-0.191 ; 0.182]$} & 0.030 & No \\
\hline Place dependence & 0.202 & {$[-0.196 ; 0.191]$} & 0.039 & No \\
\hline \multirow[t]{2}{*}{$\begin{array}{l}\text { Festival re-patronizing } \\
\text { intention }\end{array}$} & -0.161 & {$[-0.191 ; 0.191]$} & 0.098 & Yes \\
\hline & $\begin{array}{l}\text { Logarithm of the } \\
\text { composite's } \\
\text { variances ratio }(=0)\end{array}$ & $\begin{array}{l}95 \% \text { confidence } \\
\text { interval }\end{array}$ & $\mathrm{p}$-value & $\begin{array}{l}\text { Equal } \\
\text { variances? }\end{array}$ \\
\hline $\begin{array}{l}\text { Co-creation experience with } \\
\text { performers }\end{array}$ & -0.126 & {$[-0.361 ; 0.382]$} & 0.504 & Yes \\
\hline $\begin{array}{l}\text { Co-creation experience with } \\
\text { other festival goers }\end{array}$ & 0.017 & {$[-0.294 ; 0.313]$} & 0.911 & Yes \\
\hline Co-creation & -0.058 & {$[-0.326 ; 0.351]$} & 0.741 & Yes \\
\hline Festival satisfaction & 0.066 & {$[-0.300 ; 0.319]$} & 0.681 & Yes \\
\hline Place identity & -0.060 & {$[-0.318 ; 0.338]$} & 0.713 & Yes \\
\hline Place dependence & 0.038 & {$[-0.265 ; 0.277]$} & 0.783 & Yes \\
\hline $\begin{array}{l}\text { Festival re-patronizing } \\
\text { intention }\end{array}$ & 0.008 & {$[-0.310 ; 0.328]$} & 0.956 & Yes \\
\hline
\end{tabular}

Hypotheses $8 \mathrm{a}$ to $8 \mathrm{i}$ were examined using multiple methods, consisting of the permutation test, PLS-MGA, parametric test, and Welch-Satterthwaite $\mathrm{t}$ test. All methods produced converging conclusions (i.e., no difference for paths between residents and tourists based on their p-values $>0.05$ ), except H8h in which PLS-MGA recorded a statistically significant difference ( $p=0.036$ ) (see Table 8). According to Hair et al. (2018), the result of PLS-MGA is occasionally different due to its random process in the bootstrapping procedure. Nonetheless, given that the other three methods revealed non-significant differences in the paths, H8h should not be supported. In sum, the moderating effects of respondent type (resident versus tourist) were not found for the direct relationships in our model. 


\begin{tabular}{|c|c|c|c|c|c|c|c|c|}
\hline & & & & Permutation & test & $\begin{array}{l}\text { PLS- } \\
\text { MGA }\end{array}$ & $\begin{array}{l}\text { Para- } \\
\text { metric } \\
\text { Test }\end{array}$ & $\begin{array}{l}\text { Welch- } \\
\text { Satterth } \\
\text { waite t } \\
\text { Test }\end{array}$ \\
\hline & $\begin{array}{l}\text { Path } \\
\text { coefficient } \\
\mathrm{s} \text { original } \\
\text { (residents) } \\
\text { (A) }\end{array}$ & $\begin{array}{l}\text { Path } \\
\text { coefficient } \\
\mathrm{s} \text { original } \\
\text { (tourists) } \\
\text { (B) }\end{array}$ & $A-B$ & $\begin{array}{l}95 \% \\
\text { confidence } \\
\text { interval }\end{array}$ & $\begin{array}{l}\mathrm{p} \text { - } \\
\text { value }\end{array}$ & $\begin{array}{l}\mathrm{p} \text { - } \\
\text { value }\end{array}$ & $\begin{array}{l}\mathrm{p}- \\
\text { value }\end{array}$ & $\begin{array}{l}\mathrm{p}- \\
\text { value }\end{array}$ \\
\hline $\begin{array}{l}\text { H8a: } \\
\text { SCoC } \rightarrow \\
\text { FR }\end{array}$ & 0.041 & 0.042 & -0.001 & $\begin{array}{l}{[-0.176 ;} \\
0.168]\end{array}$ & 0.993 & 0.499 & 0.993 & 0.993 \\
\hline $\begin{array}{l}\text { H8b: } \\
\text { SCoC } \rightarrow \\
\text { PD }\end{array}$ & 0.253 & 0.276 & -0.023 & $\begin{array}{l}{[-0.226} \\
0.209]\end{array}$ & 0.832 & 0.578 & 0.830 & 0.836 \\
\hline $\begin{array}{l}\text { H8c: } \\
\text { SCoC } \rightarrow \\
\text { FS }\end{array}$ & 0.540 & 0.487 & 0.053 & $\begin{array}{l}{[-0.173 ;} \\
0.180]\end{array}$ & 0.576 & 0.311 & 0.553 & 0.592 \\
\hline $\begin{array}{l}\text { H8d: } \\
\text { SCoC } \rightarrow \\
\text { PI }\end{array}$ & 0.207 & 0.364 & -0.158 & $\begin{array}{l}{[-0.213 ;} \\
0.202]\end{array}$ & 0.137 & 0.939 & 0.119 & 0.125 \\
\hline $\begin{array}{l}\text { H8e: FS } \\
\rightarrow \text { PD }\end{array}$ & 0.394 & 0.310 & 0.084 & $\begin{array}{l}{[-0.226} \\
0.236]\end{array}$ & 0.469 & 0.236 & 0.462 & 0.470 \\
\hline $\begin{array}{l}\text { H8f: } \quad \text { FS } \\
\rightarrow \text { FR }\end{array}$ & 0.606 & 0.633 & -0.027 & $\begin{array}{l}{[-0.190} \\
0.201]\end{array}$ & 0.796 & 0.618 & 0.775 & 0.778 \\
\hline $\begin{array}{l}\text { H8g: FS } \\
\rightarrow \text { PI }\end{array}$ & 0.447 & 0.362 & 0.085 & $\begin{array}{l}{[-0.214} \\
0.229]\end{array}$ & 0.470 & 0.222 & 0.450 & 0.443 \\
\hline $\begin{array}{l}\text { H8h: PI } \\
\rightarrow \text { FR }\end{array}$ & 0.099 & -0.105 & 0.204 & $\begin{array}{l}{[-0.224} \\
0.226]\end{array}$ & 0.079 & 0.036 & 0.066 & 0.076 \\
\hline $\begin{array}{l}\text { H8i: PD } \\
\rightarrow \text { FR }\end{array}$ & 0.179 & 0.318 & -0.138 & $\begin{array}{l}{[-0.221} \\
0.210]\end{array}$ & 0.217 & 0.900 & 0.195 & 0.202 \\
\hline
\end{tabular}

Notes: SCoC = Satisfaction with Co-creation Experience; FS = Festival Satisfaction; PI = Place Identity; PD = Place Dependence; FR = Festival Re-patronizing Intention.

\section{DISCUSSION AND IMPLICATIONS}

\subsection{Discussion}

The previous literature has acknowledged the important role of festivals in attracting and retaining visitors (e.g., Davis, 2017; Getz, 2010). Drawing from C-D value co-creation logic, this study examined the extent to which satisfaction with co-creating a festival influenced overall festival satisfaction and place attachment, directly and indirectly contributing to festival visitors' 
re-patronizing intention. In particular, the study examined satisfaction with customer-tocustomer co-creation when the co-creators were performers and other festivals goers. Here, the customer-to-customer co-creation was primarily customer dominant and the co-creating experience with performers was part of customers' intentions. By analyzing the case of a single cultural festival experience, this study examined the relationships between these constructs, emphasizing their importance to the visitors' decisions to re-patronize the festival rather than switch to a different shared consumption cultural context.

In terms of the theoretical implications, even though previous understandings of tourism cocreation have primarily been based on S-D logic (Busser \& Shulga, 2018), this study adopted CD logic to show that customer-to-customer value co-creation for festivals is formed through customers' shared consumption to enhance the social value acquired during the festival. This contributes to the understanding and application of value theory in the context of festival tourism. The results reveal that satisfaction with co-creation had a direct positive effect on festival satisfaction, place identity and place dependence. Satisfaction with co-creation was a stronger predictor of festival satisfaction than place identity or dependence. That is, a positive evaluation of co-creation when festival goers and performers were involved, contributed to a positive evaluation of the festival and psychological bonding with the destination. To a greater extent, satisfied festival visitors enjoyed the customer-to-customer shared consumption and became attached to the destination, offering unique support for the visitors' destination experience. In this context, the festival visitors felt comfortable interacting with both the performers and other festival goers. This has also been found in other qualitative festival studies, suggesting that cocreation is essential to enhancing destination attachment (Davis, 2017; Rihova et al., 2015).

Festival satisfaction had a direct positive effect on festival re-patronizing intention and both dimensions of place attachment: place identity and place dependence. A positive evaluation of the overall festival experience contributed to developing both festival re-patronizing intention and psychological bonding with the destination. This result is consistent with Lee et al., (2012), who found that festivals played an important role in enhancing destination bonding and festival re-visiting intention.

Our results also showed that within the two dimensions of place attachment, place dependence but not place identity significantly predicted re-patronizing intention. From the place dependence perspective, the construct focused on the functional reasons attached to a specific 
destination, such as hosting a festival (Stokols \& Shumaker, 1981; Woosnam et al., 2018). Festivals can be considered unique activities taking place at destinations that provide the conditions needed to support the festival host (Brown and Raymond, 2007; Gu \& Raymond, 2008). There is also evidence that with place dependence the festival creates a functional and social space within which festival goers can connect to the destination. Individuals who connect with a place because it facilitates their specific reasons for attending a festival there are more inclined to re-patronize the festival. Although place dependence emphasizes the connections between people and places, especially through activities, (such as festivals taking place in a given setting), place identity focuses on how the setting "provides meaning and purpose to life" (Brown and Raymond, 2007: 90) without much connection to the activities. This may explain the insignificant relationship between place identity and re-patronizing intention to attend the festival.

In the literature, the importance of co-creation value to tourism has been emphasized, although the relationship between the co-creation experience and behavioral intention, especially in the context of festivals, has not been examined. Our result illustrates that although satisfaction with the co-creation experience was not a direct predictor of re-patronizing intention, festival satisfaction and then place dependence mediated the relationship between satisfaction with cocreation and festival re-patronizing intention. That is, a positive evaluation of the customer-tocustomer co-creation experience did contribute to festival visitors' re-patronizing intention; however, this relationship had to be realized through the positive effects of festival satisfaction on place dependence. This finding suggests that individuals whose festival visits are worthwhile due to a satisfactory co-creation festival experience, are more likely to develop behavioral intentions toward the festival. Underpinning this is the host community's ability to facilitate the desired festival experience. Our empirical results confirm that the previous efforts to link psychical dependence to a place have been crucial to understanding behavioral intention and cocreation (e.g., Suntikul \& Jachna, 2016), adding to the notion that satisfaction has a role in the process.

Unlike previous tourism studies on residents and tourists' co-creation at destinations (Gu \& Ryan, 2008; Hernández et al., 2007; Lin et al., 2017), our findings suggest that the moderator role of tourist/residents did not significantly influence any relationships between the constructs in the model (see Figure 2). A festival has its own ability to offer a temporary distinct environment 
and activities that can provide attendees with unique co-creation experiences (Mathis et al., 2016; Richards \& Wilson, 2006). Both tourists and residents, as festival goers who fully interact with the performers and other festival attendees, are highly likely to share similar experiences and thus have similar festival re-patronizing intentions and place dependence.

This study also found insignificant differences between residents and tourists in the relationship between place dependence and other constructs, including co-creation, satisfaction and intention. This is different from the research of Woosnam et al. (2018) in which the authors' found that the degree of tourists' place attachment was significantly higher than it was for residents. This might be because Woosnam et al. researched a religious event, whereas this study focused on a cultural festival involving a high level of co-creation among the attendees, performers and other festival goers. In place attachment, the term "place" has been expanded from its original meaning as a place of residence to a broader meaning that includes places visited (Brown \& Raymond, 2007). The festival location, the historical heritage streets of Macao, can be considered a unique place that both residents and tourists visit. This may explain the insignificant moderating effects of tourist/residents on the relationship between two dimensions of place attachment and other constructs in the model.

\subsection{Managerial implication}

On the basis of this study's results, we suggest that destination marketers focus their efforts more on managing shared consumption at festivals. Broadly, this can be done by utilizing a destination's specific physical setting to create a festival setting that facilitates the interaction among customers, which is a key item in a customer dominant festival experience. Here, the festival organizers' primary role is to support consumers' shared consumption in value creation (Heinonen et al., 2010). This suggests that festival providers should become aware of their secondary role in the customer experience. Under S-D logic, they are facilitators rather than service producers. In addition, C-D logic suggests that festival providers' activities are driven by an understanding of shared consumption in the festival tourism context.

The findings from this study provide information for festival organizers, to help them understand the important role of the co-creation experience and place dependence in improving satisfaction, which in turn increases the chances for repeat visits and word of mouth. In addition, the findings have implications for those who design and organize festivals, revealing the 
mechanism that leads from the co-creation experience to re-patronization. Specifically, the results show that satisfaction with the co-creation experience was positively related to festival satisfaction, followed by place dependence and re-patronizing intention. By providing festival goers with a satisfying co-creation experience, festival organizers are likely to achieve multiple goals, including higher satisfaction, higher place dependence, and more importantly a higher likelihood that goers will attend the event again. Further, although place identity did not connect the co-creation experience with re-patronization in this study, it was still a significant consequence of the co-creation experience.

In sum, providing goers with a satisfying co-creation experience is paramount. Festival organizers should enhance attendees' satisfaction with the co-creation experience through both the performers and other festival goers. In Macao, one of the key strategies has been to create an accessible, safe and convenient stage setting and parade route, and a friendly atmosphere that allows attendees to comfortably and confidently interact with the performers and other people. This shows how the value of a festival can be enhanced through crowd-based performance interaction. During festivals, the roles of the performers and attendees can be mixed. Attendees can dress up or join in the dancing and singing along with performers and performers can take photos of the festival with the attendees in the background. In addition, volunteers are crucial to such festivals. They co-ordinate the performers and festival goers, and encourage the attendees, especially those who lack the confidence to fully interact.

The organizers of the Macao International Parade have pursued some good managerial strategies that have enhanced the co-creation experience. Some practices encouraged interaction between the event's attendees and performers. For example, local schools, organizations, artists and arts groups have been invited to perform in the parade, which in turn has attracted their families to come and cheer for them. This practice has increased shared consumption and interaction among the local residents. In addition, when the parade reaches its final location, a one hour performance is carried out on stage. Other activities, such as children's face painting, have been organized alongside the parade route, to involve family visitors and increase the shared consumption and interaction. Other practices guarantee a safe environment and a smooth process for co-creating the festival experience. For example, the coordinators from the different government departments, including traffic and crowd control, have ensured that this activity is 
safe and enjoyable. The crowd effects have also enhanced the festival's atmosphere and have encouraged interaction among the festival goers.

The findings show that the relationship between satisfaction with the co-creation experience and festival re-patronizing intention is serially mediated by festival satisfaction and place dependence. One of the best practices of the Macao International Parade has been the design of its emotional and physical settings, where the parade route intersects historical and multi-cultural architecture on both sides. The physical settings are not only venues for high quality interactions , but link attendees with the destination. Festival organizers can increase the dependence of attendees by planning suitable activities to achieve their goals, which can mediate the influence of the co-creation experience on satisfaction. Given that the parade involves multiple settings, the festival itself highlights the beauty of the destination and provides flexibility to visitors that a single setting would not bring.

\subsection{Limitations and future research}

Despite our efforts to achieve an adequate sample size, data were only collected from a single festival. Future studies could compare and contrast different festivals to further validate the proposed model. In this study, place dependence was discovered as a mediator in the relationship between satisfaction and co-creation and festival re-patronizing intention. Because place plays a critical role in festival evaluations (Davis, 2017), additional analysis in future studies could examine how festival co-creation contributes to place branding and destination image. Due to the characteristics of this Parade, this paper focuses on the interactions between festival goers and performers and future research may also examine the interactions between attendees and other stakeholders. Also, this study utilized place identity and place dependence to understand tourists' and residents' festival experience; future studies focused on residents' place attachment could use social bonds as another dimension to understand place attachment in the tourism context. 


\section{REFERENCES}

Anholt, S. (2002). Nation branding: A continuing theme. Journal of Brand Management, 10(1), 59-60.

Arriaga, X. B., \& Agnew, C. R. (2001). Being committed: Affective, cognitive, and conative components of relationship commitment. Personality and Social Psychology Bulletin, 27(9), 1190-1203.

Auh, S., Bell, S. J., McLeod, C. S., \& Shih, E. (2007). Co-production and customer loyalty in financial services. Journal of Retailing, 83(3), 359-370.

Babin, B. J., \& Griffin, M. (1998). The nature of satisfaction: An updated examination and analysis. Journal of Business Research, 41, 127-136.

Baker, D. A., \& Crompton, J. L. (2000). Quality, satisfaction and behavioral intentions. Annals of tourism research, 27(3), 785-804.

Battarbee, K., \& Koskinen, I. (2005). Co-experience: User experience as interaction. CoDesign, 1(1), 5-18.

Beatty, S. E., Homer, P., \& Kahle, L. R. (1988). The involvement-commitment model: Theory and implications. Journal of Business Research, 16(2), 149-167.

Bee, C. C., \& Havitz, M. E. (2010). Exploring the relationship between involvement, fan attraction, psychological commitment and behavioural loyalty in a sports spectator context. International Journal of Sports Marketing and Sponsorship, 11(2), 37-54.

Binkhorst, E., \& Dekker, D. T. (2009). Agenda for co-creation tourism experience research. Journal of Hospitality Marketing \& Management, 18(2-3), 311-327.

Brown, G. \& Raymond, C. (2007) The relationship between place attachment and landscape values: Toward mapping place attachment. Applied Geography, 27: 98-111.

Biran, A., Liu, W., Li, G., \& Eichhorn, V. (2014). Consuming post-disaster destinations: The case of Sichuan, China. Annals of Tourism Research, 47, 1-17.

Busser, J. A., \& Shulga, L. V. (2018). Co-created value: Multidimensional scale and nomological network. Tourism Management, 65, 69-86.

Cabiddu, F., Lui, T. W., \& Piccoli, G. (2013). Managing value co-creation in the tourism industry. Annals of Tourism Research, 42, 86-107.

Campos, A. C., Mendes, J., Valle, P. O. D., \& Scott, N. (2018). Co-creation of tourist experiences: A literature review. Current Issues in Tourism, 21(4), 369-400.

Chang, S., \& Gibson, H. J. (2015). The relationships between four concepts (involvement, commitment, loyalty, and habit) and consistency in behavior across leisure and tourism. Tourism Management Perspectives, 13, 41-50.

Chi, C. G. Q., Ouyang, Z., \& Xu, X. (2018). Changing perceptions and reasoning process: Comparison of residents' pre-and post-event attitudes. Annals of Tourism Research, 70, 39-53.

Cole, S. T., \& Illum, S. F. (2006). Examining the mediating role of festival visitors' satisfaction in the relationship between service quality and behavioral intentions. Journal of Vacation Marketing, 12(2), 160-173.

Cole, S. \& Chancellor, H. (2009) Examining the festival attributes that impact visitor experience, satisfaction and re-visit intention. Journal of Vacation Marketing 15, 323-333.

Cultural Affairs Bureau (2017), 2017 Macao International Parade. Retrieved from http://www.icm.gov.mo/macaoparade/7/en/.

Davis, A. (2017). Experiential places or places of experience? Place identity and place attachment as mechanisms for creating festival environment. Tourism Management, 55, 49-61. 
del Barrio, M. J., Devesa, M., \& Herrero, L. C. (2012). Evaluating intangible cultural heritage: The case of cultural festivals. City, Culture and Society, 3(4), 235-244.

DSEC (2018). Tourist Arrivals. Retrieved from file:///E:/publication/nationalism\%20and\%20events/P2/E_MV_FR_2017_M12.pdf

Kil, N., Holland, S. M., Stein, T. V., \& Ko, Y. J. (2012). Place attachment as a mediator of the relationship between nature-based recreation benefits and future visit intentions. Journal of Sustainable Tourism, 20(4), 603-626.

Getz, D. (2010). The nature and scope of festival studies. International Journal of Event Management Research, 5(1), 1-47.

Getz, D., \& Page, S. J. (2016). Progress and prospects for event tourism research. Tourism Management, 52, 593-631.

Grappi, S., \& Montanari, F. (2011). The role of social identification and hedonism in affecting tourist re-patronizing behaviours: The case of an Italian festival. Tourism Management, 32(5), 1128-1140.

Grönroos, C. (2011). Value co-creation in service logic: A critical analysis. Marketing Theory, 11(3), 279-301.

Gu, H. \& Ryan, C. (2008). Place attachment, identity and community impacts of tourism - the case of a Beijing hutong. Tourism Management, 29: 637-647.

Fong. L. H. N., Fong, D. K. C., \& Law, R. (2016). A formative approach to modeling residents' perceived impacts of casino development. Journal of Travel \& Tourism Marketing, 33(8), 1181-1194.

Fong, L. H. N., Lam, L. W., \& Law, R. (2017). How locus of control shapes intention to reuse mobile apps for making hotel reservations: Evidence from Chinese consumers. Tourism Management, 61, 331-342.

Hair, J. F. J., Hult, G. T. M., Ringle, C. M., \& Sarstedt, M. (2014). A primer on partial least squares structural equation modeling (PLS-SEM). Los Angeles, CA: Sage Publications.

Hair, J. F., Hult, G. T. M., Ringle, C. M., \& Sarstedt, M. (2017). A primer on partial least squares structural equation modeling (PLS-SEM) (2nd ed.). Los Angeles, CA: Sage Publications.

Hair, J. F. J., Sarstedt, M., Ringle, C. M., \& Gudergan, S. P. (2018). Advanced issues in partial least squares structural equation modeling. Los Angeles, CA: Sage Publications.

Harkison, T. (2018). The use of co-creation within the luxury accommodation experience-myth or reality?. International Journal of Hospitality Management, 71, 11-18.

Hayes, A. F. (2017), Introduction to mediation, moderation, and conditional process analysis: A regression-based approach (2nd ed.). New York, NY: The Guildford Press.

Helkkula, A., Kelleher, C., \& Pihlstrom, M. (2012). Practices and experiences:Challenges and opportunities for value research. Journal of Service Management, 23(4), 554-570

Heinonen, K., Strandvik, T., Mickelsson, K. J., Edvardsson, B., Sundström, E. and Andersson, P., (2010). A customer-dominant logic of service. Journal of Service Management, 21(4), 531548.

Heinonen, K., \& Strandvik, T. (2015). Customer-dominant logic: Foundations and implications. Journal of Services Marketing, 29(6/7), 472-484.

Hernández, B., Hidalgo, M. C., Salazar-Laplace, M. E., \& Hess, S. (2007). Place attachment and place identity in natives and non-natives. Journal of Environmental Psychology, 27(4), 310319. 
Henseler, J., Ringle, C., \& Sarstedt, M. (2015). A new criterion for assessing discriminant validity in variance-based structural equation modeling. Journal of the Academy of Marketing Science, 43(1), 115-135.

Huertas-Valdivia, I., Llorens-Montes, F. J., \& Ruiz-Moreno, A. (2018). Achieving engagement among hospitality employees: a serial mediation model. International Journal of Contemporary Hospitality Management, 30, 217-241.

Hur, W-M., Moon, T-W., \& Ko, S-H. (2016), How employees' perceptions of CSR increase employee creativity: Mediating mechanisms of compassion at work and intrinsic motivation, Journal of Business Ethics, https://doi.org/10.1007/s10551-016-3321-5

Jensen, Ø. Y. S. T. E. I. N. (2014). Approaches for the evaluation of visitor experiences at tourist attractions. In Prebensen, N., Chen, J., \& Uysal, M. Creating experience value in tourism, (139-156).Reading, CAB International.

Imbeah, N., Hodibert, V. \& Amankwa, R. (2016). Residents' perception of host-guest interaction about Kwahu Easter Festival (KEF) as festival tourism. Africa Development and Resources Research Institute Journal, 25(9): 1-16.

Iwasaki, Y., \& Havitz, M. E. (2004). Examining relationships between leisure involvement, psychological commitment and loyalty to a recreation agency. Journal of Leisure Research, 36(1), 45-72.

Jones, M. A., \& Suh, J. (2000). Transaction-specific satisfaction and overall satisfaction: an empirical analysis. Journal of Services Marketing, 14(2), 147-159.

Kock, N., \& Hadaya, P. (2018). Minimum sample size estimation in PLS-SEM: The inverse square root and gamma-exponential methods. Information Systems Journal, 28(1), 227-261.

Lee, C. C. (2001). Predicting tourist attachment to destinations. Annals of Tourism Research, 28(1), 229-232.

Lee, J., Kyle, G. \& Scott, D. (2012). The mediating effect of place attachment on the relationship between festival satisfaction and loyalty to the festival hosting destination. Journal of Travel Research, 51(6), 754-767.

Liang, H., Saraf, N., Hu, Q., \& Xue, Y. (2007). Assimilation of enterprise systems: The effect of institutional pressures and the mediating role of top management. MIS Quarterly, 31(1), 59-87.

Lin, Z., Chen, Y., \& Filieri, R. (2017). Resident-tourist value co-creation: The role of residents' perceived tourism impacts and life satisfaction. Tourism Management, 61, 436-442.

Mathis, E. F., Kim, H. L., Uysal, M., Sirgy, J. M., \& Prebensen, N. K. (2016). The effect of cocreation experience on outcome variable. Annals of Tourism Research, 57, 62-75.

Mertler, C. A., \& Vannatta, R. A. (2010). Advanced and multivariate statistical methods (4th ed.). Glendale, CA: Pyrczak Publishing.

Milligan, M. J. (1998). Interactional past and potential: The social construction of place attachment. Symbolic Interaction, 21(1), 1-33.

Prahalad, C. K., \& Ramaswamy, V. (2004). Co-creation experiences: The next practice in value creation. Journal of Interactive Marketing, 18(3), 5-14.

Prebensen, N., Vitters $\emptyset$, J., \& Dahl, T. I. (2013). Value co-creations significance of tourist resources. Annals of Tourism Research, 42,240-261.

Prebensen, N., Chen, J., \& Uysal, M. (2014). Co-Creation of tourist experiences: Scope, definition and structure. In Prebensen, N., Chen, J., \& Uysal, M. Creating experience value in tourism, (1-11).Reading, CAB International.

Pritchard, M. P., Havitz, M. E., \& Howard, D. R. (1999). Analyzing the commitment-loyalty link in service contexts. Journal of the Academy of Marketing Science, 27(3), 333-348. 
Pine, J., \& Gilmore, J. H. (1999). The experience economy: work is theatre \& every business a stage. Boston: Harvard Business Press.

Ramkissoon, H., Smith, L. D. G., \& Kneebone, S. (2014). Visitor satisfaction and place attachment in national parks. Tourism Analysis, 19(3), 287-300.

Raymond, C. M., Brown, G., \& Weber, D. (2010). The measurement of place attachment: Personal, community, and environmental connections. Journal of Environmental Psychology, 30(4), 422-434.

Roberts, D., Hughes, M., \& Kertbo, K. (2014). Exploring consumers' motivations to engage in innovation through co-creation activities. European Journal of Marketing,48(1/2), 147-169.

Rihova, I., Buhalis, D., Moital, M., \& Gouthro, M. B. (2015). Conceptualising customer-tocustomer value co-creation in tourism. International Journal of Tourism Research, 17(4), 356-363.

Rihova, I., Buhalis, D., Gouthro, M. B., \& Moital, M. (2018). Customer-to-customer co-creation practices in tourism: Lessons from Customer-Dominant logic. Tourism Management, 67, 362375.

Richards, G. (1999). Vacations and the quality of life: Patterns and structures. Journal of Business Research, 44(3), 189-198.

Richards, G., \& Wilson, J. (2006). Developing creativity in tourist experiences: A solution to the serial reproduction of culture? Tourism management, 27(6), 1209-1223.

Ryan, C. (2010). Ways of conceptualizing the tourist experience a review of literature. Tourism Recreation Research, 35(1), 37-46.

Sharpley, R. (2014). Host perceptions of tourism: A review of the research. Tourism Management, 42, 37-49.

Shone, A., \& Parry, B. (2004). Successful event management: A practical handbook. London: Cengage Learning EMEA.

Stokols, D., \& Shumaker, S. A. (1981). People and places: A transactional view of settings. In J. Harvey (Ed.), Cognition, Social Behavior, and the Environment (pp. 441e-488). Hillsdale, NJ: Erlbaum.

Su, H. J., Cheng, K. F., \& Huang, H. H. (2011). Empirical study of destination loyalty and its antecedent: The perspective of place attachment. The Service Industries Journal, 31(16), 2721-2739.

Su, W. S., Hsu, C. C., Huang, C. H., \& Chang, L. F. (2018). Setting attributes and revisit intention as mediated by place attachment. Social Behavior and Personality: an international journal, 46(12), 1967-1981.

Suntikul, W., \& Jachna, T. (2016). The co-creation/place attachment nexus. Tourism Management, 52, 276-286.

Tongchaiprasit, P. \& Ariyabuddhiphongs, V. (2016), Creativity and turnover intention among hotel chefs: The mediating effects of job satisfaction and job stress, International Journal of Hospitality Management, 55, 33-40

Tynan, C., McKechnie, S., \& Hartley, S. (2014). Interpreting value in the customer service experience using customer-dominant logic. Journal of Marketing Management, 30(9-10), 1058-1081.

Ujang, N. (2017). Place attachment and continuity of urban place identity. Asian Journal of Environment-Behaviour Studies, 2(2), 117-132.

Vargo, S. L., \& Lusch, R. F. (2008). Service-dominant logic: Continuing the evolution. Journal of the Academy of Marketing Science, 36(1), 1-10. 
Wong, J. W. C., \& Lai, I. K. W. (2018). Evaluating value co-creation activities in exhibitions: An impact-asymmetry analysis. International Journal of Hospitality Management, 72, 118131.

Woosnam, K., Aleshinloye, K., Ribeiro, M., Stylidis, D., Jiang, J. \& Erul, E. (2018). Social determinants of place attachment at a World Heritage Site. Tourism Management, 67, 139146.

Yolal, M., Gursoy, D., Uysal, M., Kim, H. L., \& Karacaoğlu, S. (2016). Impacts of festivals and events on residents' well-being. Annals of Tourism Research, 61, 1-18.

Yi, Y., \& Gong, T. (2013). Customer value co-creation behavior: Scale development and validation. Journal of Business Research, 66(9), 1279-1284.

Zhou, Z., Su, C., Zhou, N., \& Zhang, N. (2016). Becoming friends in online brand communities: Evidence from China. Journal of Computer-Mediated Communication, 21(1), 69-86. 